\title{
Occupy Central and Constitutional Reform in Hong Kong
}

Karita Kan

\section{(2) OpenEdition \\ Journals}

Electronic version

URL: http://journals.openedition.org/chinaperspectives/6284

DOI: 10.4000/chinaperspectives.6284

ISSN: 1996-4617

\section{Publisher}

Centre d'étude français sur la Chine contemporaine

\section{Printed version}

Date of publication: 1 September 2013

Number of pages: $73-78$

ISSN: 2070-3449

\section{Electronic reference}

Karita Kan, « Occupy Central and Constitutional Reform in Hong Kong », China Perspectives [Online], 2013/3 | 2013, Online since 01 September 2013, connection on 15 September 2020. URL : http:// journals.openedition.org/chinaperspectives/6284 


\title{
CefC News Analysis
}

\section{Occupy Central and Constitutional}

\section{Reform in Hong Kong}

\author{
KARITA KAN
}

$\mathrm{T}$ hree years after the controversial 2010 electoral reform package was passed by the city's legislature, Hong Kong again stands at a critical juncture in the struggle for universal suffrage toward realising full democracy. In Article 45 of the Basic Law, the city's constitution, the selection of the chief executive by universal suffrage is stated as the "ultimate aim." However, the same article also stipulates that the selection method shall be specified "in light of the actual situation" and "in accordance with the principle of gradual and orderly progress." (1) Democrats had hoped for the introduction of universal suffrage as soon as 1997, but Article 6 of Annex I to the Basic Law stipulates that the first chief executive shall be selected in accordance with the Decision of the National People's Congress (NPC). (2) Because Article 6 only makes specification for the first chief executive, and Article 7 of the same Annex makes provisions for future amendments, the two clauses have been interpreted by democrats as containing the implicit promise that after the first administration, universal suffrage would be introduced as early as 2007. A heavy blow was dealt to such aspirations by Beijing in April 2004, when the NPC Standing Committee voted to rule out universal suffrage for the chief executive election in 2007. (3) Three years later, it further ruled out universal suffrage for the 2012 election. It was determined at the same session, however, that the election of the fifth chief executive in 2017 "may be implemented by the method of universal suffrage," and that after this all members of the Legislative Council may be elected by universal suffrage. ${ }^{(4)}$ All attention is thus on the current administration, headed by Leung Chun-ying, to launch the reform process toward delivering the first democratically elected chief of the city.As of summer 2013, however, there has been little sign that the leadership intends to commence consultation. The future chief executive, according to the Basic Law, will be elected from a pool of candidates nominated by a "broadly representative" nominating committee (timing weiyuanhui 提名委員會). Although the exact composition of the committee has yet to be decided, it is believed that Beijing will push for a makeup similar to that of the existing Election Committee (xuanju weiyuanhui 選舉委員會), which includes district representatives and lawmakers. Amendments to the Electoral Affairs Commission Ordinance will need to be enacted at least 12 months ahead, and allowing time also for any proposed reform package to be passed through the Legislative Council decisions must be made no later than the final quarter of 2014. ${ }^{(5)}$ Hence, there is urgent need to begin consultation and negotiation as soon as possible. The 1 July march, an annual rally led by the Civil Human Rights Front since the handover, saw a record number of participants since 2004 taking to the streets clamouring for the speedy implementation of democratic reform.

This essay will focus on one social movement that has grown out of this context of disillusionment and growing sense of urgency. "Occupy Central" (zhanling zhonghuan 佔領中環), as it has come to be known, is conceived by Benny Tai Yiu-ting, a moderate law professor, as a last resort strategy to force Beijing to fulfil its promise of democracy. Although it shares the name of the Occupy Wall Street movement in New York, the current campaign fights for something rather different. Section one examines the latest debate on electoral reform in Hong Kong. Section two demonstrates how Occupy Central presents a unique case study in the recent history of social movements in the Special Administrative Region (SAR). The following two sections analyse reactions to the movement and seek to answer why Occupy Central, noting how it has not only become the focus of attacks from proBeijing groups but has also led certain members of the pan-democratic camp to question its viability.

\section{Contending versions of democracy}

Following the NPC Standing Committee's 2007 resolution that Hong Kong

1. The full text of the Basic Law of the Hong Kong Special Administration Region of the People's Republic of China is available at www.basiclaw.gov.hk/en/index/index.html (accessed on 25 June 2013).

2. "Decision of the National People's Congress on the Method for the Formation of the First Government and the First Legislative Council of the Hong Kong Special Administration Region," 4 April 1990, www.legislation.gov.hk/blis_ind.nsf/CURALLENGDOC/8E4706E4D2D578D7482575EEO00E4FB6? OpenDocument (accessed on 25 June 2013).

3. "Decision of the Standing Committee of the National People's Congress on Issues Relating to the Methods for Selecting the Chief Executive of the Hong Kong Special Administrative Region in the Year 2007 and for Forming the Legislative Council of the Hong Kong Special Administrative Region in the Year 2008," 29 April 2004, www.legislation.gov.hk/blis_pdf.nsf/6799165d2fee3fa 94825755e0033e532/18425962728D2E17482575EF00290144/\$FILE/CAP_2208_e_b5.pdf (accessed on 25 June 2013). A survey on Hong Kong people's views on the Standing Committee's 2004 decision conducted by Civic Exchange is available on the think tank's website, www.civicexchange.org/wp/survey-on-hong-kong-peoples-views-on-scnpc-decision-civic-exchanges-analysis/ (accessed on 25 June 2013).

4. "Decision of the Standing Committee of the National People's Congress on Issues Relating to the Methods for Selecting the Chief Executive of the Hong Kong Special Administrative Region and for Forming the Legislative Council of the Hong Kong Special Administrative Region in the Year 2012 and on Issues Relating to Universal Suffrage," 29 December 2007, www.legislation.gov.hk/blis_ind.nsf/CURALLENGDOC/50CF52DA13DFB768482575EE000ED11A? OpenDocument (accessed on 25 June 2013).

5. Anson Chan, "The key step to universal suffrage," South China Morning Post, 8 May 2013. See also Hong Kong Transition Project, "Constitutional Reform in Hong Kong: Round Three," commissioned by the Community Development Initiative, June 2013. 


\begin{tabular}{|c|c|c|}
\hline$A$ & $\begin{array}{l}1,500 \text {-member committee with the addition of } \\
\text { district councillors to the } 1,200 \text {-member Election } \\
\text { Committee }\end{array}$ & $\begin{array}{l}\text { Secure the support of no fewer than one tenth of } \\
\text { nominating committee members; } \\
\text { OR } \\
\text { Obtain the written endorsement of at least } 2 \% \text { of } \\
\text { registered voters in geographical elections }\end{array}$ \\
\hline B & $\begin{array}{l}400 \text {-member committee elected by voters } \\
\text { in } 20 \text { constituencies }\end{array}$ & $\begin{array}{l}\text { Secure the support of no fewer than one tenth of } \\
\text { nominating committee members }\end{array}$ \\
\hline & $\begin{array}{l}500 \text {-member committee made up of all legislators } \\
\text { and district councillors }\end{array}$ & $\begin{array}{l}\text { Secure the support of no fewer than one tenth of } \\
\text { nominating committee members; } \\
\text { OR } \\
\text { Obtain the written endorsement of at least } 2 \% \text { of } \\
\text { registered voters in geographical elections }\end{array}$ \\
\hline
\end{tabular}

may elect its own chief executive in 2017 through universal suffrage, the debate has turned to the actual mechanisms by which the city's next head will be chosen. The overwhelming number of blank votes (54.6\%) cast at the mock vote formally known as the 3.23 Civil Referendum Project, held by the Public Opinion Programme of the University of Hong Kong on the three official candidates ahead of the 2012 chief executive election, certainly made the central government nervous about the prospect of introducing popular elections in the SAR with a limited pool of vetted candidates. ${ }^{(6)}$ Testing the waters, Politburo Standing Committee memberYu Zhengsheng was the first high-level figure to remark that the SAR chief executive must love China and love Hong Kong (ai guo ai Gang 愛國愛港). He warned of the growing power of "subversive" forces in the territory, fearing that Hong Kong may "become a base and the bridgehead from which to subvert the socialist system in the mainland." (7)Yu's remarks were reiterated days later by Central Liaison Office director Zhang Xiaoming, who added that the future chief executive must be trusted by the central government (huo zhongyang xinren 獲中央信任) and that there must be a filtering mechanism (shaixuan 篩選) to ensure that a person who opposes (butuo, duili de ren 不妥、對立的人) Beijing will not be elected. ${ }^{(8)}$ These remarks raised fears that the central government intends to screen out undesirable candidates before citizens get the chance to vote.

The bone of contention focuses on the provision in Article 45 that the chief executive shall be elected by universal suffrage "upon nomination by a broadly representative nominating committee in accordance with democratic procedures." For the pan-democrats, the formation of this nominating committee must itself follow strict democratic procedures. Different groups within the camp have come up with their own proposals. The most representative thus far is that put forward by the Alliance for True Democracy (zhenpuxuan lianmeng 真普選聯盟), a coalition formed in March 2013 joining 27 legislators from 12 political groups. ${ }^{(9)}$ In its Initial Views for Consultation announced in May, the Alliance suggested that nominating committee members should be elected by all 3.2 million registered voters on a "one person, one vote" (yiren yipiao 一人一票) basis. ${ }^{(10)}$ In early July, the Scholar Panel of the Alliance, which gathers a group of academics including convenor Joseph Cheng and Chinese University politics professor Ma Ngok, formally announced proposals for uni- versal suffrage in the 2017 chief executive election. (11) They came up with three plans with regard to the composition of the nominating committee:

- The first is to add 400 democratically elected district councillors to the 1,200 members that will be formed along the lines of the current Election Committee. Minus the seats in the Election Committee elected by district councillors, the new nominating committee will have around 1,500 members.

- The second is to have a 400-member directly elected nominating committee, to be elected by all voters registered in geographical constituencies by proportional representation.

- The third is to have a 500-member nominating committee made up of all district councillors elected in 2015 and legislative councillors elected in 2016

6. A total of 222,990 votes were cast, via the Internet, smartphone and in person, over the two-day polling period with the following results: $54.6 \%$ blank votes; $17.8 \%$ for Leung Chun-ying; $16.3 \%$ for Henry Tang; $11.4 \%$ for Albert Ho. The activity report for the project is available for download at the Public Opinion Programme website, http://hkupop.hku.hk/english/release/ release929_popvote323_activity_report_en.pdf (accessed on 11 July 2013).

7. Eddie Luk and Winnie Chong, "Subversion warning on 2017 CE race," The Standard, 7 March 2013, www.thestandard.com.hk/news_detail.asp?pp_cat=30\&art_id=131766\&sid=39159171\&con_typ e=3 (accessed on 25 June 2013)

8. "Zhang Xiaoming: Teshou puxuan yaoyou shaixuan" (Zhang Xiaoming: There must be filtering mechanisms for chief executive election), Ming Pao, 10 March 2013.

9. The Alliance for True Democracy represented the first concrete attempt to unite the pan-democratic camp after the split in 2010 over strategic differences in the second round of constitutional reform debate. Convened by City University politics professor Joseph Cheng, it joins members from the more moderate Democratic Party and Civic Party and the more radical League of Social Democrats and People Power. Its goal is to strive for the realisation of "double-universal suffrage" for the chief executive and the Legislative Council. Its official presence is on Facebook, https://www.facebook.com/pages/\%E7\%9C\%9F\%E6\%99\%AE\%E9\%81\%B8\%E8\%81\%AF\%E7\% 9B\%9F-Alliance-for-True-Democracy/635752756440759 (accessed on 10 July 2013).

10. The full text of the Initial Views is available on the Alliance's Facebook site, http://goo.gl/neRGAU (accessed on 10 July 2013). See also "Zhenpulian teshou fang'an yuedi ke paiban" (Proposal on chief executive election by Alliance for True Democracy will be confirmed by end of the month), Oriental Daily, 20 June 2013, http://orientaldaily.on.cc/cnt/news/20130620/00176_018.html (accessed on 25 June 2013).

11. The full text of the Scholar Panel's proposals are available on the Alliance's Facebook site, http://goo.gl/8RMWe (accessed on 11 July 2013). See also "Zhenpuxuan Lian ti san xuanju fang'an" (Alliance for True Democracy put forward three electoral proposals), Sing Tao Daily, 10 July 2013. 
For the nomination procedure, under all three proposals any candidate who has secured the support of no less than one tenth of nominating committee members can gain an entry ticket to run in the final popular election. For the first and third proposals, however, because committee members are not all directly elected by all voters, an alternative qualifying route to the final race is to obtain the written endorsement of $2 \%$ of the voting population, or about 70,000 to 80,000 voters. This additional channel will respect ordinary voters' right to nominate and ensure that candidates with reasonable public support can enter the race. ${ }^{(12)}$ For the final popular election, the Scholar Panel recommends the adoption of a "two-round run-off" system. In the long run, the Alliance wants the nominating committee scrapped and the chief executive elected directly by all voters.

The recommendation by the Alliance is the most comprehensive to have emerged from the pan-democrats thus far and the one that has obtained the most consensual support within the camp. Based on the above three proposals, various pan-democratic parties will now consult public opinion before consolidating one concrete proposal to be announced by the end of 2013. Meanwhile, a few other pro-democracy groups have also put forward proposals, some of which suggest that the committee should be made up of all 3.2 million voters citywide, and that anyone who has collected 50,000 (People Power) or 100,000 (Scholarism) endorsements should be eligible to become a candidate. ${ }^{(13)}$

The Alliance's so-called "2\% route" of joint endorsement has already drawn criticism from Beijing-loyalist lawmakers ${ }^{(14)}$ such as Regina Ip ${ }^{(15)}$ and Elsie Leung, deputy director of the Basic Law Committee. (16) Michael Tien, a local deputy to the NPC, said that an election without a screening mechanism could lead to the "ludicrous" situation of 10,000 people running for the post. ${ }^{(17)}$ Instead, the pro-establishment camp voiced support for the idea of introducing a preliminary election within the nominating committee ${ }^{(18)}$ to decide which candidates can go forward to the final race. In other words, candidates considered unfavourable to Beijing may face two barriers before they can proceed to the popular vote: they must first secure a certain number of nominations from within the committee, and then survive the internal vote. Given that pro-Beijing members will likely dominate the future nominating committee, as is the case in the extant Election Committee, it is possible that candidates from the pro-democracy camp could be screened out before the final poll. The pre-election mechanism is thus widely criticised as a way for the central government to manipulate electoral results.

\section{Occupation as civil disobedience}

As ongoing debates confirm the wide chasm between the kind of electoral mechanisms Beijing finds acceptable and the full-fledged universal suffrage demanded by pro-democracy forces, the challenge for the pan-democratic camp is to find the best negotiating strategy going forward. This is where Benny Tai Yiu-ting, a law professor at the University of Hong Kong, floated the idea of staging an act of large-scale civil disobedience (gongmin kangming 公民抗命). To Tai, the fatal flaw in the pan-democrats' strategy is their regrettable lack of bargaining power. Aside from using its one-third objection vote in the Legislative Council to block constitutional proposals, the prodemocracy camp simply has no "nuclear bomb" at hand to strengthen its negotiating position vis-à-vis Beijing. Tai believes that Hong Kong citizens must be willing to deploy "a most destructive weapon" (zuida shashangli wuqi 最大殺傷力武器). In a January 2013 op-ed, Tai proposed rallying at least 10,000 citizens to participate in a non-violent sit-in to immobilise
Central should no substantial progress be made by summer 2014. ${ }^{(19)}$ Central is the financial and commercial heart of Hong Kong and the lifeline of the city's prosperity. The idea is to have participants blocking off entire sections of roads in Central such that traffic will be paralysed and economic activities will be disrupted. The greater the number of participants, the more difficult it would be for the police to clear the ground without using force, and the heavier the political cost for the SAR government.

What perhaps distinguishes this campaign from previous movements is its focus on "absolute non-violence" as a way to seize moral authority. It is the organisers' belief that the movement can only be successful if the majority of Hong Kong people sees it as a legitimate form of struggle. In a bid to secure even the support of conservative members of society, Occupy Central is positioned as a peaceful demonstration in which violent means of struggle are ruled out. Participants must take an oath not to use force or resist law enforcement, and violators will be ousted from the operation. Notably, to emphasise self-sacrifice and the solemnity of the struggle, participants are encouraged to give themselves up to the authorities after the movement is over and to file no defence in trial (zhudong zishou bing yu fating buzuo kangbian 主動自首並於法庭不作抗讋). They must hence be willing to bear any legal consequences for breaking the law. Key supporters of the movement have said they expect "a lot of people will go to jail, a lot of people will lose their professional qualifications" should arrests take place en masse. (20) Occupy organisers have initially focused on mobilising the middle-aged and the middle class: neither strongly supportive of the government nor highly critical of it, this "silent majority" makes up $50 \%$ to $70 \%$ of the population.

On 27 March, Benny Tai was joined by his two partners, Sociology Professor Chan Kin-man and Reverend Chu Yiu-ming of Chai Wan Baptist Church, at a solemn press meeting during which the movement's manifesto (xinnian shu 信念書) was announced. Titled "Let Love and Peace Occupy Central" (rang ai yu heping zhanling zhonghuan 讓愛與和平佔領中環), the manifesto highlights three fundamental convictions that participants in the campaign should share: that the electoral system of Hong Kong must satisfy international standards in relation to universal suffrage; that the electoral reform proposal should be decided by means of a democratic process; and that any act of civil disobedience, though illegal, must be "absolutely non-violent." (21)

12. Joshua But, "Pan-democrats to seek public opinion on three proposals for 2017 election," South China Morning Post, 10 July 2013.

13. Joshua But, "Pan-democrats to roll out 2017 suffrage plan six months early," South China Morning Post, 2 May 2013, and "Xuemin sichao pao zhenggai fang'an" (Scholarism made constitutional reform proposal), Am730, 24 June 2013.

14. Kelly Ip, "Bid to widen role of voters," The Standard, 11 July 2013, www.thestandard.com.hk/ news_detail.asp?pp_cat=30\&art_id=135417\&sid=39938189\&con_type $=1$ (accessed 11 July 2013).

15. "Congmin lianshu bufu jibenfa" (Regina Ip: Citizen nomination not in line with the Basic Law), Sing Tao Daily, 10 July 2013. See also Joshua But, "Pan-democrats to seek public opinion on three proposals for 2017 election," ibid.

16. Joshua But, Gary Cheung, and Tony Cheung, "'One man, one vote' urged for 2017 chief executive panel," South China Morning Post, 9 May 2013.

17. Colleen Lee and Phila Sun, "Activist puts out Occupy Central action plan," South China Morning Post, 15 April 2013.

18. Eddie Luk, "Double election for CE draws fire," The Standard, 11 March 2013, www.thestandard.com.hk/news_detail.asp?pp_cat=30\&art_id=131859\&sid=39185066\&_con_typ $\mathrm{e}=3$ (accessed on 25 June 2013).

19. Benny Tai, "Gongmin kangming de zuida shashangli wuqi" (The most destructive weapon of civil disobedience), Hong Kong Economic Journal, 16 January 2013.

20. Melody Chan, "Albert Ho Chun-yan promised to resign to pave way for the Occupy Central movement," Independent Media, 12 March 2013, www.inmediahk.net/albert-ho-chun-yan-promisedresign-pave-way-occupy-central-movement (accessed on 10 July 2013).

21. The full text of the manifesto is available on the official website of Occupy Central, http://oclphk.wordpress.com/2013/03/27/english/ (accessed on 25 June 2013). 
Four basic steps of the movement are also outlined: there will first be a covenant-signing day planned for summer 2013 at which participants will pledge their commitment to the action; followed by deliberation day (shangtao ri 商討日) and citizen authorisation (gongmin shouquan 公民授 權), and culminating in the final act of civil disobedience.

Work is in progress towards producing an electoral reform proposal. Deliberation days will be held, according to principles of deliberative democracy laid out in the works of American scholars Bruce Ackerman and James Fishkin, to come up with such a proposal, which will then go through an electronic voting platform for a citywide vote as an endorsement for the final plan. It is anticipated that the government will then throw out its own counter-proposal, one that will likely make partial compromises without fully complying with the democrats' demands. At this time, the resignation of a legislator, possibly that of Democratic Party lawmaker Albert Ho Chunyan from his Legislative Council "super seat," will take place to trigger a byelection or pseudo-referendum to provide a platform for citizens to express their support or opposition to the government's proposed package. (22) Should the people vote against it but the leadership refuse to budge, the blockade of Central will go ahead in summer 2014. Smaller-scale non-cooperative actions will accompany the blockade, such as the draping of SAR flags across streets for signature collection. (23)

With leaders meeting and plans unfolding, Occupy Central has been gaining momentum since its conception just nine months ago. The first deliberation day, attended by 700 participants including 600 invited guests and 100 randomly selected citizens, was successfully held in early June and produced a list of seven main points to be discussed at the next deliberation day. ${ }^{(24)}$ The campaign also received a great boost at the annual 1 July march. Organisers recruited a team of more than 100 volunteers to help collect donations and advertise the campaign, successfully raising HK\$800,000 from supporters. (25) Perhaps a greater boost to the occupy organisers, however, was simply the increased turnout at the march itself. Civil Human Rights Front put participation figures at 430,000, an increase from 400,000 in 2012, 218,000 in 2011 and 52,000 in 2010. (26) The trend of growing discontent is evident: it is a matter of tactic and will on the part of Occupy Central activists to capture this popular sentiment and turn it into a politically-definitive movement.

\section{Reactions to Occupy Central}

The reaction of government officials to the campaign is an important indication of how events will likely unfold in the lead-up to summer 2014. What has happened thus far has only added fuel to the occupy movement. In a move widely seen as targeted political persecution, in early May a volunteer at the movement's office was arrested for assisting in the organisation of an unauthorised assembly at the 1 July demonstration back in 2011. (27) Melody Chan, a 26-year-old trainee solicitor, is a key supporter of Occupy Central, and her interview with Benny Tai, which she wrote for the local current affairs blog Independent Media, played a critical role in spreading and popularising the campaign through online channels. ${ }^{(28)}$ Although the police claimed to be unaware of Chan's involvement in the campaign, the fact that the arrest took place almost two years after the alleged offense was committed invariably raised suspicion that it was politically motivated. (29) Weeks later, chief executive Leung Chun-ying issued his strongest warning yet to Occupy Central organisers by saying that the government will not tolerate law-breaking activities. He said that it is impossible for the movement to be lawful and peaceful, and that organisers are "breaking the law for the sake of it" (wei fanfa er fanfa 為犯法而犯法). ${ }^{(30)}$

Pro-establishment figures have quickly aligned their views with that of the government. These critics have resorted to three main lines of argument. The first, like Leung's, is to condemn Occupy Central as unnecessarily radical and working against the spirit of the law. Wen Wei Po attacked the organisers for "stirring up young professionals to knowingly break the law" (shandong nianqing zhuanye renshi zhifa fanfa 煽動年青專業人士知法犯法). Legislator Regina Ip alleged that the "real, covert purpose" of the organisers is to trigger a violent confrontation and unleash the People's Liberation Army, "provoking a mini-Tiananmen incident in Hong Kong." (31) A second criticism is that the movement sacrifices collective interests for personal political ambition. Business groups are particularly outspoken on the economic losses Occupy Central could incur, citing the concerns of small and medium enterprises. ${ }^{(32)}$ The Chinese General Chamber of Commerce and the Chinese Manufacturers' Association of Hong Kong, for example, placed half-page advertisements condemning the campaign for eroding Hong Kong's competitiveness. ${ }^{(33)}$ Economics professor Frances Lui, who compared Occupy Central to "terrorist" activities, even demanded participants to each pay a daily punitive fine of HK\$160,000 to cover the loss, according to his estimation, of at least HK\$1.6 billion for each day that Central is paralysed. (34) The third criticism is that the campaign lacks broad-based popular support. ${ }^{(35)}$ This, as we shall discuss, is an issue raised also by concerned supporters of Occupy Central within the pro-democracy camp.

22. Melody Chan, "Albert Ho Chun-yan promised to resign to pave way for the Occupy Central movement," ibid.

23. Eddie Luk, "Last Stop:Central," The Standard, 15 March 2013, www.thestandard.com.hk/news_detail.asp?pp_cat=36\&art_id=132058\&sid=39225152\&_con_type $=3 \& d$ _str $=20130315$ (accessed on 25 June 2013).

24. "Zhanzhong shouge shangtaori" (The first deliberation day of Occupy Central), Sing Tao Daily, 10 June 2013, http://goo.gl/kVYCYM (accessed on 10 July 2013).

25. "Zhanzhong sanzi jiezhan chou bashi wan" (Three organisers of Occupy Central raised HK\$800,000 on the street), Ming Pao, 2 July 2013.

26. Police said that 66,000 participated in the march at its peak. A University of Hong Kong statistician estimated turnout at 103,000, while the University of Hong Kong's Public Opinion Programme estimated turnout at 93,000 .

27. Johnny Tam and Tony Cheung, "Occupy Central volunteer charged over July 1 protest," South China Morning Post, 9 May 2013.

28. Melody Chan, "Yifa dayi: gongmin kangming de zhadan" (Fulfilling justice through the law: The bomb of civil disobedience), Independent Media, 22 January 2013, www.inmediahk.net/ node/1015347 (accessed on 25 June 2013).

29. Simpson Cheung and Tony Cheung, "Police chief defends Occupy Central activist's arrest," South China Morning Post, 10 May 2013.

30. "Liang pi zhanzhong" (Leung criticizes Occupy Central), Ming Pao, 10 June 2013.

31. Regina Ip, "Occupy Central provocations won't help to build a consensus," South China Morning Post, 9 June 2013

32. "Gongshang jinrong jie naobao" (Commercial and financial sector condemns Occupy Central), Wen Wei Po, 21 May 2013, http://paper.wenweipo.com/2013/05/21/HK1305210003.htm (accessed on 25 June 2013)

33. It was reported that the Central Liaison Office had urged the city's four major chambers to place joint adverts condemning Occupy Central but did not succeed. See Bonnie Chen, "Occupy Central worries SMEs," The Standard. See copy of the Chinese Manufacturer's Association of Hong Kong's advertisement on the House News, 20 May 2013, http://goo.gl/VtnSO0 (accessed on 25 June 2013).

34. Yang Sheng, "Occupy disrupts social order," China Daily, 31 May 2013. Frances Lui, "Zhanling zhonghuan peichang duoshao" (How much compensation should Occupy Central pay," Sky Post, 3 April 2013, http://goo.gl/EMwgko (accessed on 25 June 2013).

35. Pro-establishment newspapers have repeatedly cited surveys conducted by the Hong Kong Research Association, a think tank believed to be close to Beijing. According to the association's poll results, some $63 \%$ of interviewees are against Occupy Central, $55 \%$ agree that the campaign erodes the core value of the rule of law, and $54 \%$ agree that it will cost great damage to the economy. "Diaocha zhi Gang shimin fandui zhanling zhonghuan zhe bili shangsheng" (Survey shows that proportion of Hong Kong citizens opposing Occupy Central is on the rise), Hong Kong China News Agency, 25 June 2013, www.hkcna.hk/content/2013/0625/200357.shtml (accessed on 27 June 2013). The official website of Hong Kong Research Association is www.rahk.org/intro/intro01.asp. 
The past half of the year saw new activism from Beijing-loyalist organisations in attacking Occupy Central and rallying citizens to oppose the movement. The more radical of these groups, such as Caring Hong Kong Power (aihu Xianggang liliang 愛護香港力量) and Voice of Loving Hong Kong (aiGang zhisheng 愛港之聲), were often present at many of the movement's key events to cause disruption and sabotage. ${ }^{(36)}$ The movement Defend Central (shouhu zhonghuan 守護中環), led by Voice of Loving Hong Kong action team leader Chan Kwong-man, is also attracting followers through social network Facebook. The group vowed to launch a Protect Hong Kong movement (huGang xingdong 護港行動) and set up an action team to monitor the behaviour of Occupy Central activists (jiancha zhanzhong xingdongzu 監 察佔中行動組). It also planned to mobilise 10,000 people to rally in opposition of Occupy Central as a direct gesture of counteraction. ${ }^{(37)}$

Schools have again become a major battlefield as fear of the further radicalisation of the younger generation prevails: a prestigious local school became the target of acrimonious attacks after it invited Benny Tai to deliver a lecture, (38) and two secondary schools subsequently withdrew their invitation to Tai. ${ }^{(39)}$ An academic exchange program called "Co-China," co-hosted by Occupy organiser Chan Kin-man bringing together participants from Taiwan, mainland China, and Hong Kong on the theme of nativist movements, also received threats that "severe consequences" would follow if the summer camp were not immediately cancelled. (40) It is apparent that the authorities fear that Occupy Central will further lead the city's young people "astray" by encouraging them to disregard the law through civil disobedience.

There is basis for their growing concern, as Hong Kong is about to see its first post-colonial generation reaching voting age. Should the city hold its first direct election for the chief executive then, this first post-colonial generation will have a powerful influence on the outcome, and this influence is only going to grow stronger as the older generation, which has much stronger identification with mainland China and appears less dissatisfied with the Hong Kong government, passes away. ${ }^{(41)}$ Parents and teachers have accordingly become the targets of united front efforts. The Central Liaison Office has reportedly worked through district loyalist organisations to reach out to parent-teacher associations. The Beijing-friendly Kowloon Women's Organisations Federation, for example, was reportedly instructed to hold a joint meeting with five parent-teacher associations in the Kowloon district to discuss plans to co-organise a forum preaching the demerits of Occupy Central, recruiting parents and teachers to help discourage the young from supporting unlawful activity. The Hong Kong Federation of Education Workers, a pro-government union, praised teachers for being "rational" after its survey found that $60 \%$ of teachers polled said they do not support civil disobedience as a way of making political demands. ${ }^{(42)}$

\section{Concerns raised by democrats}

Within the pro-democracy camp, opinions on Occupy Central are not uniformly positive. While most applaud the spirit motivating the movement and indicate their willingness to participate in it, others have questioned its practicality and whether the campaign can truly be representative and inclusive. One pressing concern is what role Occupy Central will play in negotiating with the government and whether it will compromise. Surely the tough lesson learnt by the Democratic Party in the 2009-2010 round of electoral reform consultation is still fresh in people's minds: by accepting closed-door negotiation with the Central Liaison Office and compromising on a conservative package, the party was labelled a "traitor" and was pun- ished by voters in the subsequent election. Similarly, when Martin Lee Chuming recently suggested that a nominating committee with a makeup similar to the current 1,200-member Election Committee is acceptable if it guarantees that the five candidates receiving the most nominations (possibly including one democrat) can enter the popular vote, his idea was warmly welcomed by government loyalists, but emphatically denounced by pan-democrats. ${ }^{(43)}$ Lee eventually retracted his comments and apologised to fellow pan-democrats for "letting them down." (44)

A second and related concern is this: how much change do Hong Kong citizens want? Research has found that although there is strong majority support for fixing the present electoral system, the reform options supported by the majority are "hardly radical alternatives," some being "reversions to past practice or extensions of types of elections held in the present system in new ways." (45) For example, on the formation of the nominating committee, nearly half of those polled support making the 1,200-member Election Committee as it is currently elected into the new nominating committee. Granted that there is much greater public support for more radical reform options such as "abolishing all functional constituencies in the Legislative Council" (73\%) and "changing the chief executive nominating process to popular primary system with top two candidates competing in direct election" (81\%), the lack of strong opposition to conservative arrangements is equally suggestive. If Occupy Central is seen by the majority as making unnecessarily radical demands, it may lose popular support. A poll conducted by the Public Opinion Programme of the University of Hong Kong in April sheds further light on this issue. ${ }^{(46)}$ Interviewees were asked to what extent they support or oppose the following proposal: regarding the 2017 chief executive election, before candidates enter the one person, one vote race, there should first be selection within the nominating committee to ensure that all chief executive candidates will not oppose the Bei-

36. Caring Hong Kong Power was established in June 2011 with the stated objective of protecting the government from attacks by "Hong Kong-harming" political groups and media outlets. The group's convener is Chan Ching-sum; see an interview with Chan by Stuart Lau, "Hong Kong full of 'political rogues', says activist Chan Ching-sum," South China Morning Post, 29 April 2013. The group's official page is on Wordpress, http://chkp.org/wordpress/ (accessed on 12 July 2013). Voice of Loving Hong Kong was formed by businessman Ko Tat-pun in October 2012 with the similar goal of opposing "forces" that disturb Hong Kong's stability and prosperity. By April 2013 it had attracted some 3,000 members with 30 active core members, most being native Hong Kongers. Its official page is on Facebook, https://zh-hk.facebook.com/voiceoflovinghk (accessed on 12 July 2013).

37. "AiGang zhisheng zuzhi wanren fan zhanzhong" (Voice of Loving Hong Kong mobilizes 10,000 to oppose Occupy Central), Sing Tao, 27 June 2013, http://news.stnn.cc/hongkong/ 201306/t20130627_1907996.html (accessed on 3 July 2013).

38. Caring Hong Kong Power published an essay in Wen Wei Po warning against the "evil" influence of Occupy Central. "Buneng rang zhanzhong mozhang shenjin xiaoyuan" (We cannot let the evil hand of Occupy Central enter schools), Wen Wei Po, 24 May 2013, http://paper.wenweipo.com/2013/05/24/PL1305240007.htm (accessed on 28 June 2013).

39. Tony Cheung, "2 schools back out of Occupy Central talks under pressure: Benny Tai," South China Morning Post, 20 June 2013.

40. See the public letter posted by on the summer camp's website, http://goo.gl/dtlkJ (accessed on 28 June 2013).

41. See the detailed statistical analysis presented in Hong Kong Transition Project, "Constitutional Reform in Hong Kong: Round Three," ibid.

42. "Occupy central lacks teachers' support," RTHK English News, 11 June 2013, http://rthk.hk/rthk/ news/englishnews/20130611/news_20130611_56_927934.htm (accessed on 3 July 2013).

43. Joshua But, "Martin Lee pulls controversial plan for Hong Kong chief executive poll reform," South China Morning Post, 12 April 2013.

44. "Li Zhuming zhengshi xuanbu shouhui fang'an" (Martin Lee officially retracts his proposal," Apple Daily, 11 April 2013, http://hk.apple.nextmedia.com/realtime/news/20130411/51341996 (accessed on 9 July 2013)

45. Hong Kong Transition Project, ibid., p. 133.

46. The research findings are available for download on the website of the Public Opinion Programme, http://hkupop.hku.hk/english/report/mpCEnOCC/index.html (accessed on 9 July 2013). 
Table 2 - Attitude toward Occupy Central by age group, based on a 3-5 July 2013 survey undertaken by the Public Opinion Programme of the University of Hong Kong

\begin{tabular}{|l|c|c|c|}
\hline $\begin{array}{l}\text { Attitude toward } \\
\text { Occupy Central }\end{array}$ & $\begin{array}{c}\text { Age group } \\
18-29\end{array}$ & $\begin{array}{c}\text { Age group } \\
30-49\end{array}$ & $\begin{array}{c}\text { Age group } \\
50 \text { or above }\end{array}$ \\
\hline Support & $41 \%$ & $33 \%$ & $27 \%$ \\
\hline Half-half & $22 \%$ & $14 \%$ & $9 \%$ \\
\hline Oppose & $31 \%$ & $44 \%$ & $54 \%$ \\
\hline $\begin{array}{l}\text { Don't know I } \\
\text { Hard to say }\end{array}$ & $6 \%$ & $8 \%$ & $11 \%$ \\
\hline
\end{tabular}

Source: http://hkupop.hku.hk/english/report/mpCEnOCC/index.html (accessed on 9 July 2013).

jing government. This is the screening mechanism proposal widely condemned by the democrats. Surprisingly, $44 \%$ of those polled expressed support for the plan in contrast to $35 \%$ against. The same poll also asked interviewees whether they support Occupy Central as a means to fight for universal suffrage: $51 \%$ said they oppose it, double the $25 \%$ that indicated support. A more recent poll conducted by the same programme saw support for Occupy Central increase to $32 \%$ after the 1 July march, but opposition remains as strong as $46 \% .{ }^{(47)}$ Notably, the middle-aged group that organisers had at first sought to draw out remains predominantly opposed to the movement (See Table 2).

If these figures can be taken as indicative, then Occupy Central still has a considerable way to go in establishing broad-based popular support. It is still seen by many as a radical movement despite its peaceful intentions. As some critics point out, the movement's emphasis on middle-class participation - based on the rationale that the middle class has less to worry about in terms of career and finance - has made other social groups such as the working class and the young feel less involved in the struggle. ${ }^{(48)}$ The business community is another group whose support Occupy organisers should actively solicit by addressing their concerns over the campaign's negative effect on the city's investment environment. In this regard, the recent effort by former Chief Secretary Anson Chan to re-launch Citizens' Commission on Constitutional Development under the new name of Hong Kong 2020 aims to open a dialogue with the business sector and to enlist its support for constitutional reform. She believes that many businesspeople support true democracy as they can see the inefficacy of the current political system, but they need new channels of communication with the pan-democratic camp to overcome their isolation from the political debate. ${ }^{(49)}$

As Benny Tai said, the worst case scenario looming on organisers' mind is not that protestors are arrested en masse - this, he believes, would only provoke public outrage and incite more people to rally against the government's excessive behaviour - but rather the campaign's demise amidst widespread criticism from an unsympathetic, unmoved public. A critical question to ask is whether the people of Hong Kong see themselves as part of this struggle. Most movements in the city's past with the strongest rallying power have capitalised on the intense concentration of public anger on certain government initiatives, be it national education, high-speed rail construction, or Article 23. They built on common opposition to highly unpopular policies, took place spontaneously, and gathered momentum rapidly, culminating in massive turnouts. Occupy Central, on the other hand, must unite democracy supporters with different ideas about the extent of reform needed. There is as yet no concrete government plan to build common opposition around. Going forward, the movement will need to take on the demanding task of consensus-building to aggregate demands from society and articulate a coherent, well-defined set of objectives that represents what the movement is fighting for. While the proposals by the Alliance for True Democracy may serve as a good starting point, the pan-democratic camp must be prepared for a long fight.

\section{Conclusion}

While Hong Kong citizens took to the street to demand democratic change, chief executive Leung Chun-ying reiterated the SAR government's "greatest sincerity and commitment" in launching consultation for the implementation of universal suffrage. ${ }^{(50)}$ The Xinhua report on Leung's speech was titled "Government seeks change, maintains stability" - a headline that probably sums up Beijing's concern and priority in dealing with the territory that is becoming more difficult to manage by the day. Making incremental concessions while delaying genuine reform may no longer guarantee the stability Beijing so prizes.

Of course, there are different groups and factions within the leadership, some with more reformist outlooks than others. Professor Jiang Shigong, an adviser to the central government, said that the failure to push forward change would hurt Beijing's moral image and leave the SAR government in a deadlocked state. ${ }^{(51)}$ But there has also been a recent spate of conservative thinking finding outlets in various Party publications, most notably People's University law professor Yang Xiaoqing's controversial paper on the inappropriateness of Western constitutionalism for communist China. ${ }^{(52)}$ The ideological battle within the Party-state is far from settled, and will continue to have implications on how the leadership reacts to Hong Kong's demands. There is no doubt that those concerned about democratic progress in the mainland will be keeping a watchful eye on how Occupy Central unfolds in the SAR.

\section{Karita Kan is a doctoral student in politics at the University of Oxford and is a research assistant at CEFC (karitakan@gmail.com).}

CEFC News Analysis is compiled from the CEFC's fortnightly selection of Press Highlights, available at www.cefc.com.hk.

47. "Qiyi hou cheng zhanzhong shengzhi 23\%" (Support for Occupy Central increases to 32\% after 1 July march), Ming Pao, 10 July 2013.

48. See, for example, Joshua Wong, "Chonghui qidian pouxi zhanling zhonghuan" (Back to the beginning for an analysis of Occupy Central), Ming Pao, 2 April 2013. Grace Tsoi, "Occupy Central 2.0," ibid.

49. Tony Cheung, "Commerce key for universal suffrage, says Anson," South China Morning Post, 25 April 2013. The website for Hong Kong 2020 is http://hongkong2020.com/ (accessed on 24 July 2013).

50. "CY Leung: Government seeks change, maintains stability," Xinhua, 1 July 2013, www.chinadaily.com.cn/china/2013-07/01/content_16696473.htm (accessed on 10 July 2013).

51. Gary Cheung and Emily Tsang, "Beijing is urged to heed marchers," South China Morning Post, 3 July 2013.

52. Yang Xiaoging, "Xianzheng yu renmin minzhu zhidu zhi bijiao yanjiu" (A comparative study of constitutionalism and people's democracy), Qiushi, May 2013, www.qstheory.cn/hqwg/ 2013/201310/201305/t20130521_232618.htm (accessed on 11 July 2013). 